\title{
ニトロゲナーゼ活性中心の構造と機能に関する新展開
}

\section{Recent Progress in Research on the Structures and Functions of Nitrogenase Active Sites}

大木 靖弘* (名古屋大学大学院理学研究科) Department of Chemistry, Graduate School of Science, Nagoya University, Yasuhiro Ohki* Received July 29, 2015; E-mail: ohki@chem.nagoya-u.ac.jp

\begin{abstract}
Nirtogenases are a class of enzymes that catalyze the reduction of $\mathrm{N}_{2}$ to $\mathrm{NH}_{3}$ under ambient conditions in the presence of protons and electrons. The active site of the most prevalent nitrogense is called as the FeMo-cofactor, which is often designated as the M-cluster. It consists of one molybdenum, seven irons, and several sulfur atoms, and represents the most complex metal-sulfur cluster in biology. Some homologues containing vanadium or iron in place of molybdenum exist in alternative nitrogenases, while a precursor of FeMo-cofactor was also identified as an all-iron homologue. Recent crystallographic and biochemical studies on nitrogenases uncovered some important clues about the structurefunction relationship of the nitrogenase active sites, such as the precise structure of the FeMo-cofactor, unique catalytic functions of the FeMo-cofactor and its homologues, and the detailed mechanistic insights in the nitrogen fixation. Transition-metal mediated conversion of small molecules that contain triple bonds has been of interest to the community of coordination chemistry, and this contribution introduces some important progresses in the nitrogenase chemistry/biochemistry made in recent years.
\end{abstract}

\section{1.はじめに}

大気中の $\mathrm{N}_{2}$ をプロトン存在下で還元してアンモニア に変換する酵素は、ニトロゲナーゼと呼ばれる。その代 表的な活性中心は FeMo-cofactorであり、Fig. 1 に示す 通り、計 8 つ金属原子と 9 つの $\mathrm{S}$ 原子を含み、中心 にある C 原子は三角柱状に配列した 6 つの Fe を架橋し ている。この金属 硫黄クラスターは、 末端の Fe に結合し たシステインの硫 黄と、Mo に配位し たヒスチジン残基 のイミダゾールに よってタンパク中

連絡先著者名: 大木靖弘

連絡先 : 464-8602 名古屋市千種区不老町

名古屋大学大学院理学研究科

Tel: 052-789-2476 Fax: 052-789-2943

Corresponding Author: Yasuhiro Ohki

Address: Furo-cho, Chikusa-ku, Nagoya 464-8602, Japan

Keywords: nitrogenase, enzyme, molybdenum, vanadium, iron, sulfur, cluster, nitrogen fixation
に保持され、Mo にはさらに $R$-ホモクエン酸がキレー 卜配位している。FeMo-cofactor の他にも、Moの代わり に V や Fe を持つ FeV-cofactor や FeFe-cofactor も、場合 によって発現することが知られている ${ }^{1)}$ 。また、ニトロ ゲナーゼが還元できる基質は、 $\mathrm{N}_{2}$ の他にも $\mathrm{HC} \equiv \mathrm{CH}$ や $[\mathrm{CN}]^{-}$等があり、本稿で以下紹介する通り、 $\mathrm{CO}$ や $\mathrm{CO}_{2}$ を還元し C-C 結合を形成する反応も、最近見いだされ ている。

錯体化学の観点から興味の対象になるのは、ニトロゲ ナーゼ活性中心の構造と機能の関係、すなわち活性中心 をなす金属 - 硫黄クラスターがどのように $\mathrm{N}_{2}$ 等の基質 を捕捉し還元するかであり、また合成化学の観点からは、 複雑な金属 - 硫黄クラスター構造の生成過程にも興味が もたれる。最近 5 年ほどの間に、ニトロゲナーゼ活性中 心の構造や生合成、窒素固定メカニズム、および基質還 元機能に関して大きな進展が見られたことから、本稿で はそれらの成果を整理し紹介するとともに、活性中心を なす金属 - 硫黄クラスターの働きについて議論したい。

\section{FeMo-cofactor や前駆体の構造解析とクラスター 生成過程}

FeMo-cofactor の構造が初めて報告されたのは 1992 年 であるが 2)、当時のデー夕精度では詳細な構造決定は困 難であった。より高精度のデータが得られた 2002 年に は、クラスターの中心に 6 つ鉄を架橋する軽原子 $\mathrm{X}$ $(\mathrm{X}=\mathrm{O}, \mathrm{N}$, or $\mathrm{C})$ が存在することが判明し $\left.{ }^{3}\right)$ 、最終的には Fig. 1 に示す通り $\mathrm{X}=\mathrm{C}$ であることが、2011 年に確認さ れた ${ }^{4,5)}$ 。このとき用いられたデー夕類は、高分解能 $(1.0$ Å)の X 線結晶回折データから求めた詳細な電子密度解 析結果と、電子スピンエコー変調 (ESEEM)、およびX 線発光分光 $(\mathrm{XES})$ であった。

分光法に基づく $\mathrm{X}=\mathrm{C}$ の帰属は、以下の通り行われ た。まずESEEM 測定においては、タンパクを構成す るアミノ酸や FeMo-cofactor の中心原子を含めた、全て

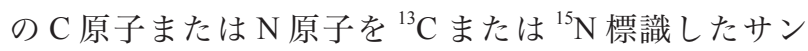
プルを用い、休止状態にある FeMo-cofactorの電子スピ ン $(S=3 / 2)$ と ${ }^{13} \mathrm{C}$ または ${ }^{15} \mathrm{~N}$ の核スピン $(I=1 / 2)$ の間に 見られる超微細構造を調べた。結果として ${ }^{13} \mathrm{C}$ 標識した 場合に大きなカップリングが見られたことから、FeMocofactorの中心に C 原子が存在することが示唆された。 


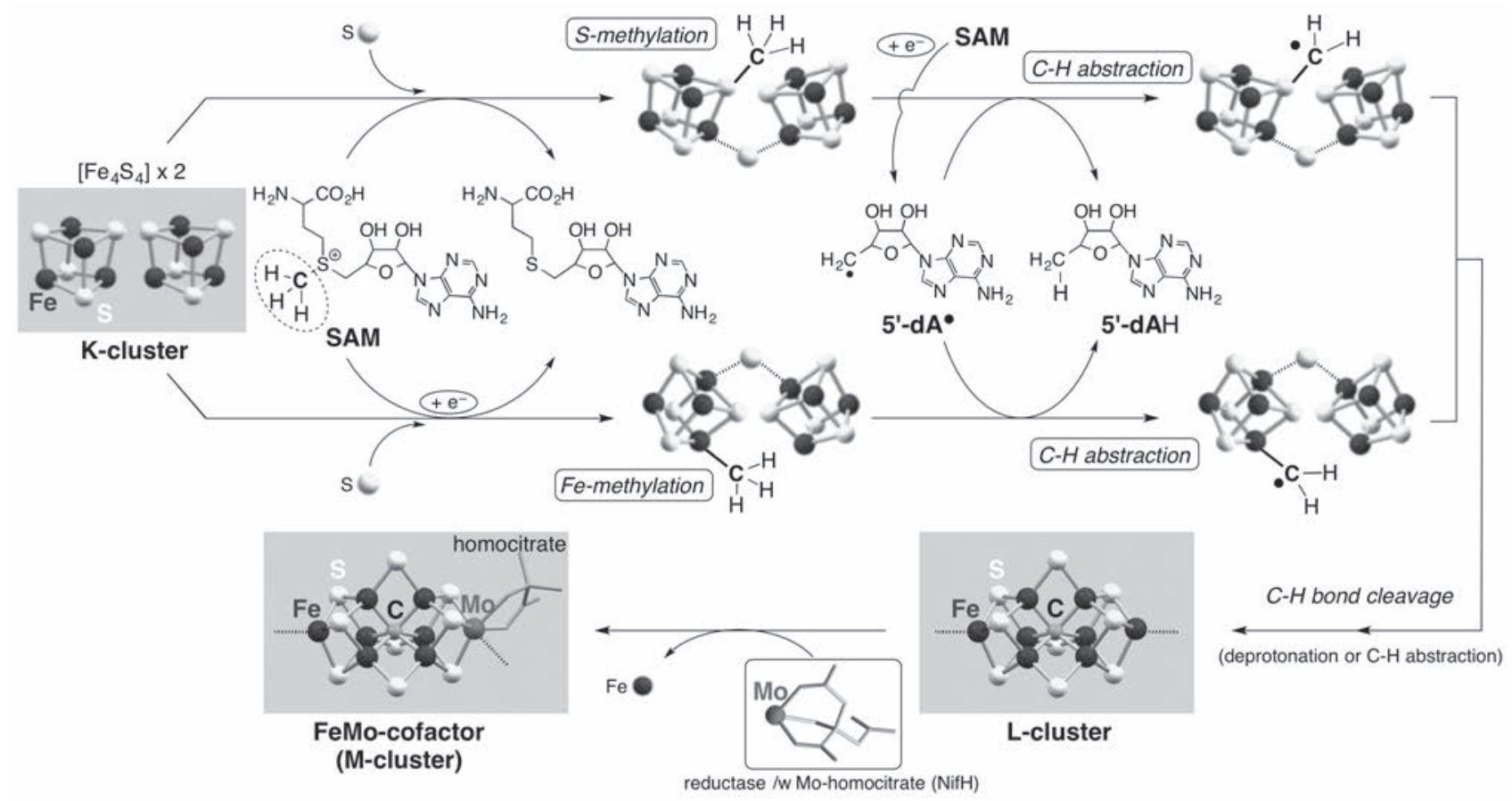

Fig. 2 Possible biosynthetic pathways to the FeMo-cofactor from K-cluster through L-cluster. Mechanisms of carbon insertion are also proposed. SAM $=$ S-adenosyl-methionine, $5^{\prime}$-dA $=$ 5'-deoxyadenosyl moiety.

またXES 測定においては、Feの1s電子を排出したと ころへ $\mathrm{S}$ の $3 \mathrm{~s}$ 電子が充填される際の放出エネルギーを 主に観測した。このとき、FeMo-cofactor 以外にタンパ クに含まれる Fe-S 成分 (P-cluster) の影響を差し引くこ とで、FeMo-cofactor 由来のスペクトル成分を求め、さ らに DFT 計算で求めた構造に基づいてシュミレーショ ンしたXES スペクトルと実測を比較することで、 $\mathrm{X}=\mathrm{C}$ であると帰属した。

FeMo-cofactorの構造が最終決定された翌年の 2012 年には、中心 $\mathrm{C}$ 原子の由来が $\mathrm{S}-$ アデノシルメチオニ ン $(\mathrm{SAM})$ の $\mathrm{S}-\mathrm{CH}_{3}$ 部位であることが、放射性の ${ }^{14} \mathrm{C}$ を 用いた同位体標識実験により明らかにされた ${ }^{6}$ 。また この中心 C 原子は、酵素反応過程で放出されないこと も確認された ${ }^{7)}$ 。 $\mathrm{SAM}$ 由来の $\mathrm{CH}_{3}$ 基が取り込まれるの は、FeMo-cofactor の生合成過程のうち、比較的早い段 階である (Fig. 2)。このときK-cluster と呼ばれる一対の キュバン型 $\left[\mathrm{Fe}_{4} \mathrm{~S}_{4}\right]$ クラスターが連結し、中心 $\mathrm{C}$ 原子を もつ $\left[\mathrm{Fe}_{8} \mathrm{~S}_{9} \mathrm{C}\right]$ 骨格の L-cluster（Fig. 2 右下）が生成する と考えられている。続いて、L-clusterに含まれる Fe の 一つがMo に置換され、FeMo-cofactorへと変換される。 この一連の過程では、K-cluster $\rightarrow$ L-cluster $\rightarrow$ FeMocofactor と変換される度に別のタンパクへと金属 - 硫 黄クラスターが移送されることも特徵的である。

L-cluster が生成する過程では、 $\mathrm{SAM}$ 由来の $\mathrm{CH}_{3}$ 基が $\mathrm{C}-\mathrm{H}$ 結合を持たない $\mathrm{C}$ 原子へと変換される。この $\mathrm{C}-\mathrm{H}$ 結合切断反応の少なくとも一部は、SAM から別途生じ るアデノシルラジカル (Fig. 2 の 5'-dA・) が H 原子を引 き抜くことで達成される。つまり $\mathrm{SAM}$ は、 $\mathrm{CH}_{3}$ 基およ
びアデノシルラジカルの供給源として、二通りの役割を 果たしている。なお、SAMのS-アデノシル結合を開裂 させて、アデノシルラジカル（とメチオニン）を生じる 反応は、radical-SAM ${ }^{8)}$ と総称される $\mathrm{SAM}$ 含有 $\mathrm{Fe}-\mathrm{S}$ タン パクの代表的な機能であり、Co-C 結合をラジカル開裂 させてアデノシルラジカルを生じるアデノシルコバラミ ン (補酵素 $\left.\mathrm{B}_{12}\right)$ と同様に、生体内の様々なラジカル反 応に利用される。

FeMo-cofactor の前駆体である L-cluster (Fig. 2 右下) は、中心 $\mathrm{C}$ 原子を持つ $\left[\mathrm{Fe}_{8} \mathrm{~S}_{9} \mathrm{C}\right]$ クラスターであることが、 タンパク結晶構造解析により確認された ${ }^{9}$ 。ただし中心 $\mathrm{C}$ 原子の存在は、分解能 (2.6 ̊) が不十分な回折データ ではなく、前々段落に述べた生化学実験の結果 ${ }^{6)}$ に基づ いて証明されている。L-cluster は、FeMo-cofactor へ変 換された後に別のタンパクへと移送されるが、L-cluster を保持するタンパクの構造は、移送先である FeMocofactor を取り込むタンパクの構造に似ている。

これらの研究成果は、これまで不明とされていた FeMo-cofactor の生成過程の多くを明らかにするととも に、複雑なクラスター合成過程を化学の視点で理解する 一助にもなると考えられる。

\section{3. $\mathrm{N}_{2}$ 等の基質捕捉段階に関係する新たな知見}

FeMo-cofactor の詳細構造が明らかにされてもなお、 $\mathrm{N}_{2}$ 等の基質が FeMo-cofactorのどこに相互作用し、どの ように還元されるのか容易には想像できない。なぜなら ば、我々が知る Fig. 1 の構造は休止状態 (resting state) で あり、この状態から 4 電子と 4 プロトンが加わり $\mathrm{N}_{2}$ を 


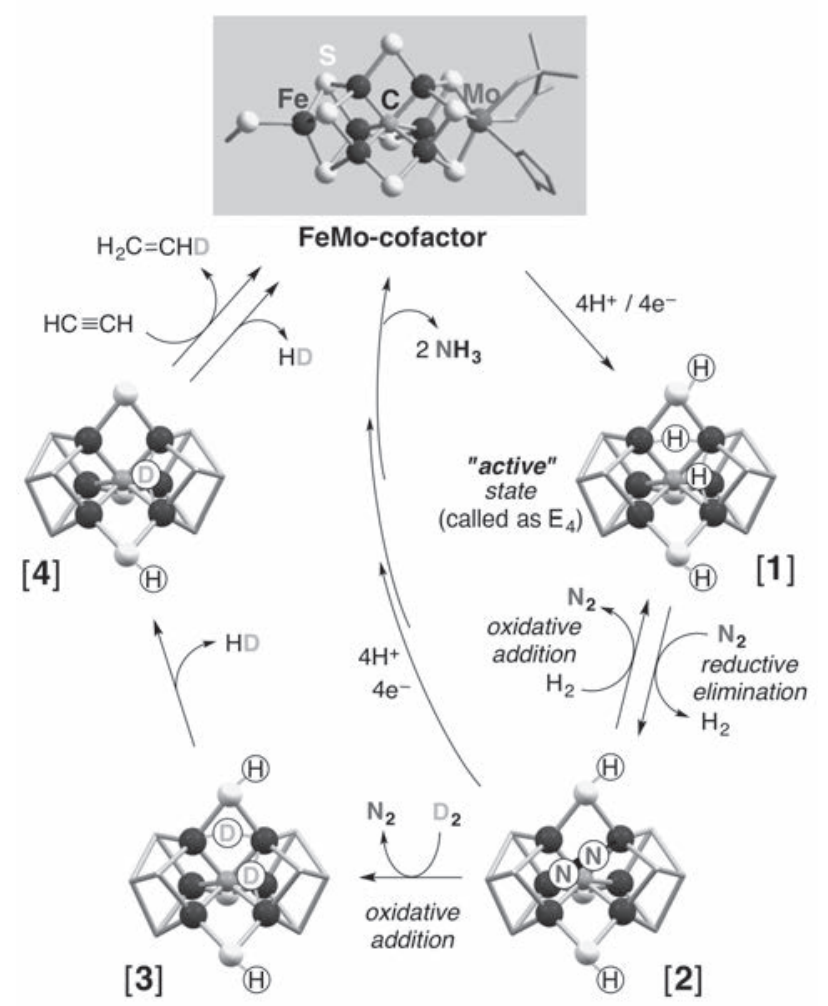

Fig. 3 Proposed mechanism for $\mathrm{N}_{2}$ binding / $\mathrm{H}_{2}$ elimination from the "active state" [1] and the $\mathrm{N}_{2}$-dependent formation of $\mathrm{HD}$ and $\mathrm{C}_{2} \mathrm{H}_{3} \mathrm{D}$ in the presence of $\mathrm{D}_{2}$.

捕捉できる活性状態では、休止状態と構造が異なる可能 性が高いためである。

$\mathrm{N}_{2}$ を捕捉できる活性状態の FeMo-cofactor には Fe 間 を架橋する二つのヒドリド Fe-H-Fe (と二つの S-H 部位) が存在すること ${ }^{10,11)}$ 、ならびに $\mathrm{N}_{2}$ の捕捉段階で $\mathrm{H}_{2}$ が還 元的に脱離し、この反応が可逆であること ${ }^{12,13)}$ を示唆 する実験結果が、最近得られた (Fig. 3)。例えば、FeMocofactor によるプロトン $\left(\mathrm{H}_{2} \mathrm{O}\right)$ 還元を実施した場合、 $\mathrm{D}_{2}$ 雾囲気下の反応で検出できたのは $\mathrm{H}^{+}$を還元して生じた $\mathrm{H}_{2}$ と気相に加えた $\mathrm{D}_{2}$ だけであったが、気相に $\mathrm{D}_{2}$ と $\mathrm{N}_{2}$ を共存させると、 $\mathrm{HD}$ も生成し始めた。同様に、 $\mathrm{H}_{2} \mathrm{O}$ バ ッファー中、 $\mathrm{D}_{2} / \mathrm{N}_{2}$ 混合雾囲気下で同位体標識したアセ チレン $\mathrm{H}^{13} \mathrm{C} \equiv{ }^{13} \mathrm{CH}$ を還元すると、重水素化したエチレン ${ }^{13} \mathrm{C}_{2} \mathrm{H}_{3} \mathrm{D}$ や ${ }^{13} \mathrm{C}_{2} \mathrm{H}_{2} \mathrm{D}_{2}$ が一部生成したが、 $\mathrm{N}_{2}$ が共存しない 条件ではエチレンに重水素が取り込まれなかった。従 って、これらの重水素取り込み反応では、活性状態の FeMo-cofactor (Fig. 3 [1]) と N $\mathrm{N}_{2}$ の反応が関与すると考元 られる。

前段落に記載した、 $\mathrm{D}_{2}$ もくく $\mathrm{D}_{2} / \mathrm{N}_{2}$ 雾囲気下の反 応結果を解釈する際に、活性状態の FeMo-cofactor [1] が $\mathrm{Fe}-\mathrm{H}-\mathrm{Fe}$ と S-H 部位を二つずつ含み ${ }^{10,11)} 、 \mathrm{~N}_{2}$ との反応 ([1] $\rightleftarrows[2] ）$ が可逆に起こる ${ }^{13)}$ との前提を取り入れる と、 $\mathrm{N}_{2}$ 捕捉体 [2] が気相の $\mathrm{D}_{2}$ と反応し、二つの Fe-D$\mathrm{Fe}$ を持つ活性状態 [3] 生じる可能性を導ける。続いて、 S-H 部位による Fe-D-Fe の直接プロトン化を経て HD が

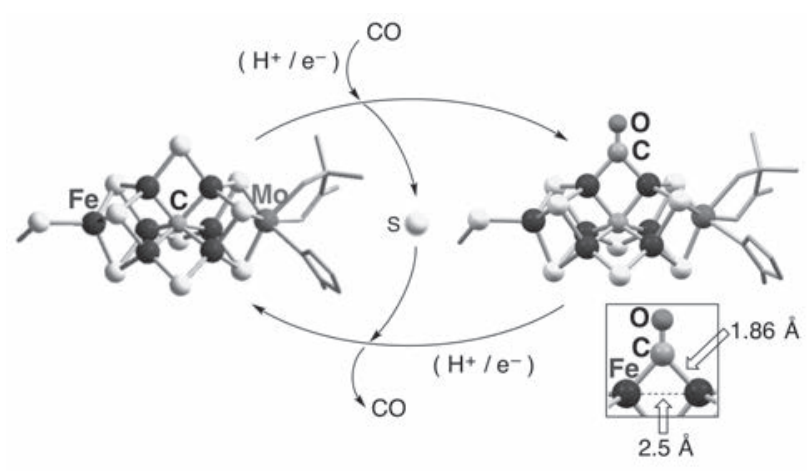

Fig. 4 Reversible formation of one of the CO-inhibited forms of FeMo-cofactor under turnover conditions.

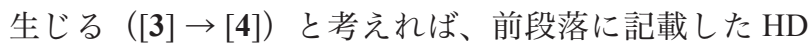
の生成を理解できる。また、HDが脱離した後の FeMocofactor [4]によってアセチレンが還元されれば、部分 的に重水素化したエチレン $\mathrm{C}_{2} \mathrm{H}_{3} \mathrm{D}$ の生成も説明できる。 活性状態の FeMo-cofactor [1] と $\mathrm{N}_{2}$ の反応が可逆に起こ ることは、 $\mathrm{N}_{2}$ 捕捉体 [2] を凍結したサンプルの EPR シ グナル減衰速度と $\mathrm{H}_{2} / \mathrm{N}_{2}$ 分圧の関係を追跡した実験から も支持されている ${ }^{13)}$ 。なお、 $\mathrm{N}_{2}$ 捕捉体 [2] の凍結サンプ ルからは、 $\mathrm{H}_{2}$ が存在しない場合でも $\mathrm{N}_{2}$ が徐々に脱離し、 この場合は休止状態の FeMo-cofactor に 2 電子と 2 プロ トンを加えた状態 (Fig. 3 [4] 相当) を生じる。さらにこ こから $\mathrm{H}_{2}$ が不可逆に脱離することで、休止状態に至る。

$\mathrm{N}_{2}$ と等電子体である $\mathrm{CO}$ も、活性状態の FeMocofactor に配位すること、また CO が配位すると FeMocofactor と $\mathrm{N}_{2}$ の反応が阻害されることが知られている。 $\mathrm{CO}$ が一つあるいは二つ配位した、二種類の CO- 阻害体 のうち、CO が一つ配位したものの結晶構造が、2014 年 に決定された (Fig. 4 右) $)^{14)}$ 。最も興味深い構造的特徵は、 FeMo-cofactor の中央部で二つの Fe を架橋するスルフィ ドの一つが消失し、代わりに CO が架橋していることで ある。この CO- 阻害体の結晶サンプルを酵素反応に適 したバッファーに浸すと、架橋 $\mathrm{CO}$ が脱離し、酵素反応 活性が回復（再活性化）することも確認された。再活性 化した結晶サンプルに含まれる FeMo-cofactorでは、元 のスルフィドが CO の代わりに Fe 間を架橋している。 つまり、S 原子の解離と $\mathrm{CO}$ の配位を伴う CO- 阻害体の 生成は、可逆に起こることが分かる。また、CO-阻害体 の生成に伴って外れた $\mathrm{S}$ 原子は、元の場所から約 $22 \AA$ 離れた場所に捕捉されている可能性があると、同じタン パク結晶構造解析に基づいて提案されている。実際、再 活性化して S 原子が元通り Fe 間を架橋すると、捕捉さ れた $\mathrm{S}$ 原子と想定する場所の電子密度が減少する。

以上に紹介した最近の研究成果は、FeMo-cofactor が 中央部にある $\mathrm{Fe}$ を用いて $\mathrm{N}_{2}$ に代表される反応基質を 捕捉する可能性を示唆している。少なくとも $\mathrm{CO}$ が $\mathrm{Fe}$ に配位することは、前段落に述べた結晶構造 (Fig. 4) に より証明されており、アルキン類やヒドラジン類が $\mathrm{Fe}$ 
に配位することも、基質還元活性や基質捕捉型 FeMocofactorの分光データと FeMo-cofactorの周囲にあるア ミノ酸残基の関係を調査した研究成果 ${ }^{15)} に よ り$ 強く支 持されている。 $\mathrm{N}_{2}$ が $\mathrm{Fe}$ に配位することを直接証明する データは今なお存在しないものの、 $\mathrm{N}_{2}$ を捕捉する活性 状態が二つの $\mathrm{Fe}-\mathrm{H}-\mathrm{Fe}$ を持つこと ${ }^{10,11)}$ と、 $\mathrm{N}_{2}$ の捕捉と $\mathrm{H}_{2}$ の還元的脱離が協奏的に起こると考えられること ${ }^{12,13)}$ は、 $\mathrm{N}_{2}$ が Feに配位することと矛盾しない。さらに、高 精度のタンパク結晶構造と分子動力学計算に基づいて提 案された基質の運搬経路（チャンネル）は、タンパク表 層から FeMo-cofactor の Fe に向けて伸びている ${ }^{16)}$

仮に FeMo-cofactor の $\mathrm{N}_{2}$ 捕捉部位が $\mathrm{Fe}$ であるとした 場合、次に浮かぶ疑問は、どのように反応点を空けるか である。現在までの研究成果を整理すると、CO- 阻害体 (Fig. 4 右)のように FeMo-cofactor のスルフィド $(\mu-\mathrm{S})$ を 解離させる、あるいは FeMo-cofactor の中心 $\mu_{6}$ - 原子と $\mathrm{Fe}$ の結合を開裂させる、の二通りの可能性が考えられ る。なお後者は、主に錯体化学者によって提起されてい $3^{17,18,19)}$ 。

\section{4. $\mathrm{C}_{1}$ 基質の還元と C-C 結合形成反応}

ニトロゲナーゼは $\mathrm{N}_{2}$ を還元する酵素であるが、冒頭 や前項に述べた通り、アセチレンやシアン化物イオン等 の非天然基質も還元することが知られている。特に最近、 $\mathrm{V}$ を含むニトロゲナーゼ（活性中心は FeV-cofactor）を 主に用い、 $\mathrm{C}_{1}$ 基質の還元とともに C-C 結合が形成され る反応が見出されている (Fig. 5)。

発見の契機は、V-ニトロゲナーゼを用いて CO 雾囲気 下でプロトン還元反応を行った場合、消費される試剤の 量論に整合性がない点を見逃さなかったことである。プ ロトン還元による $\mathrm{H}_{2}$ 生成は、FeMo-cofactor を用いた場 合には、CO 雾囲気下でも $\mathrm{Ar}$ 雾囲気下と同程度に進行 するが、FeV-cofactorを用いると、CO 雾囲気下では活 性が 35\% ほど低下する。その一方で、電子供給に必要 な ATP の消費量が低下しないことを疑問に感じた Ribbe らは、反応後の気相成分を調べ、エチレン、エタン、プ ロパンの存在を確認した (Fig. 5 (1) 左) ) $^{20)}$ 。これらの $\mathrm{C}_{2}$ 〜 $\mathrm{C}_{3}$ 化合物に含まれる $\mathrm{C}, \mathrm{H}$ 原子が、それぞれ $\mathrm{CO}, \mathrm{H}_{2} \mathrm{O}$ バッファー由来であることは、 ${ }^{13} \mathrm{CO}$ および $\mathrm{D}_{2} \mathrm{O}$ 標識実

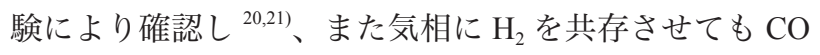
の還元生成物には取り込まれず、むしろ反応を阻害する ことも確かめられた ${ }^{22)}$ 。

この発見を契機として、FeV-cofactor および関連クラス ターによる CO の還元と C-C 結合生成反応が重点的に検 討されている。FeMo-cofactor は CO を還元できないと従 来考えられていたが、FeV-cofactorより 3 桁近く活性が低 いものの CO を還元できること (Fig. 5 (2) 左 $)^{22) 、 F e M o-~}$ cofactor の周囲にあるアミノ酸残基を変化させて反応空

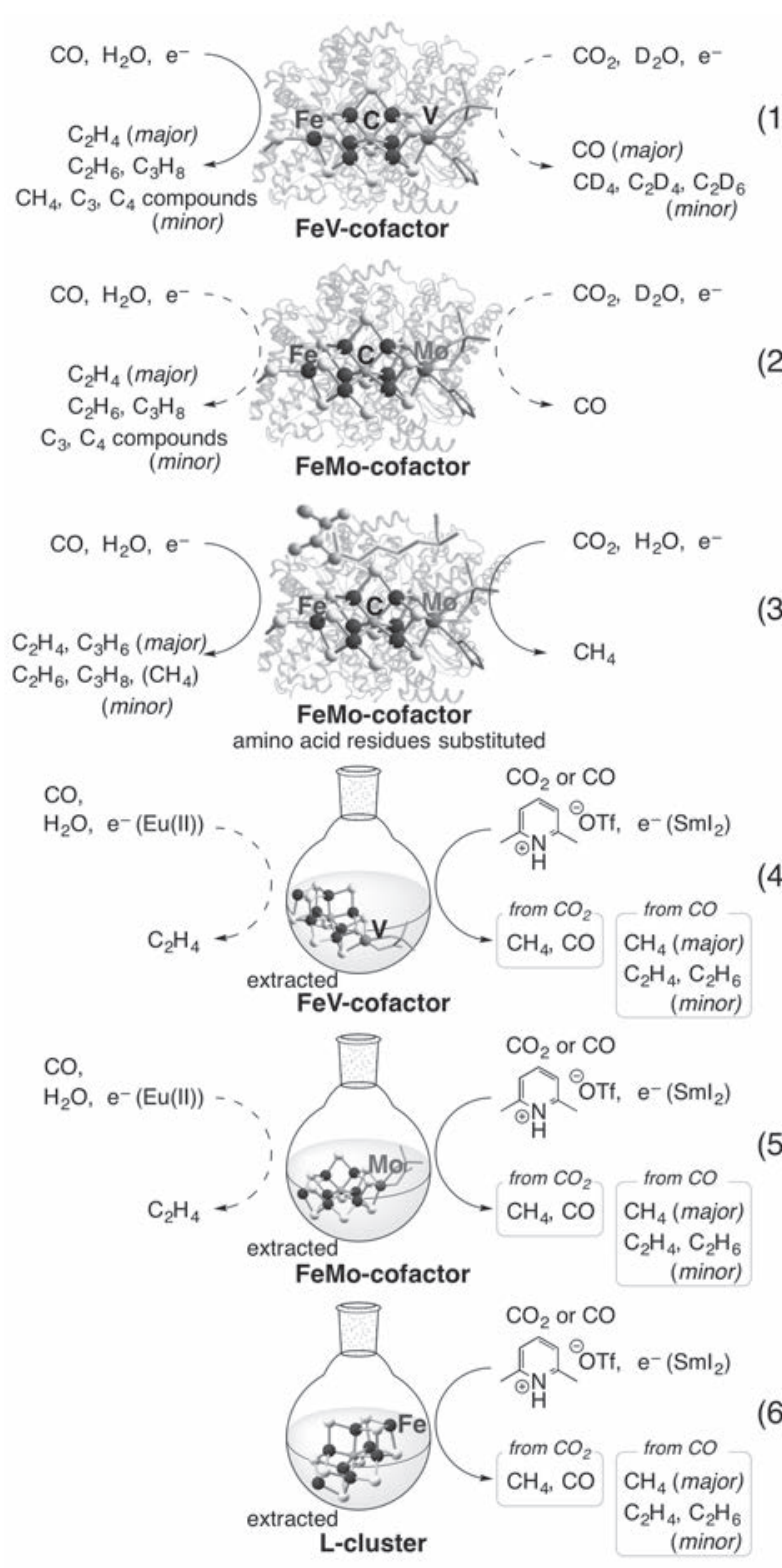

(1)

Fig. 5 Reduction of $C_{1}$ substrates by FeM-cofactor ( $\left.M=V, M o\right)$ or L-cluster leading to the $\mathrm{C}-\mathrm{C}$ bond formation.

間を広げると CO 還元活性を向上できること (Fig. 5 (3) 左 $)^{23)} 、 \mathrm{FeV}$-cofactor, FeMo-cofactor ともに主生成物であ る $\mathrm{C}_{2} \sim \mathrm{C}_{3}$ 化合物に加えて少量の $\mathrm{CH}_{4}$ や極微量の $\mathrm{C}_{4}$ 化

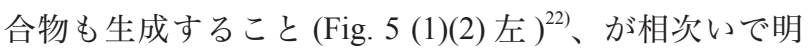
らかにされた。

還元する $\mathrm{C}_{1}$ 基質を $\mathrm{CO}_{2}$ に変え、 $\mathrm{D}_{2} \mathrm{O}$ 中で反応を実施 すると、FeV-cofactor からは $\mathrm{CO}, \mathrm{CD}_{4}, \mathrm{C}_{2} \mathrm{D}_{4}, \mathrm{C}_{2} \mathrm{D}_{6}$ が生成 し (Fig. 5 (1) 右)、FeMo-cofactor からは CO が生成した が (Fig. 5 (2) 右)、これらの還元生成物は用いたニトロ ゲナーゼに対して化学量論量未満に留まった ${ }^{24)}$ 。 $\mathrm{CO}_{2}$ の 還元活性は、FeMo-cofactor 周囲のアミノ酸残基を変え ることで 2 桁程度向上し、このとき主生成物はメタンに 変わることも明らかにされた (Fig. 5 (3) 右) $)^{25)}$ 。

さらに、用いる FeV-cofactor や FeMo-cofactor を夕 ンパクから抽出し、これらが分解する前に、還元試薬 
として $\mathrm{Eu}(\mathrm{II})$ 化合物を加えて $\mathrm{H}_{2} \mathrm{O}$ バッファー中で $\mathrm{CO}$ や $[\mathrm{CN}]^{-}$を還元する反応も検討されている (Fig. 5 (4) (5) 左 $)^{26)}$ 。この条件では、CO の還元はほとんど進行せ ず、 $[\mathrm{CN}]^{-}$を還元して生成する $\mathrm{NH}_{3}$ はクラスターに対し て最大 $15 \sim 18$ 当量、炭化水素は主生成物のエチレン で 3.6 〜 5.8 当量であった。これらの反応活性は、より 強い還元剤である $\mathrm{SmI}_{2}$ を用いることで向上することも 見出された (Fig. 5 (4)(5)(6) 右 $)^{27)}$ 。 $\mathrm{SmI}_{2}$ と $\mathrm{H}_{2} \mathrm{O}$ の直接反 応を回避するために有機溶媒を用い、 $\mathrm{H}_{2} \mathrm{O}$ に代わるプ ロトン源としてルチジン - HOTf 付加体を用いると、CO の還元反応では、FeV-cofactor を用いた場合に触媒回転 数 $(\mathrm{TON})$ が 2.7、FeMo-cofactor では TON = 3.0、また FeMo-cofactor の前駆体である L-cluster (Fig. 2 右下) で は $\mathrm{TON}=4.5$ であった。 $[\mathrm{CN}]^{-}$の還元反応も促進され、 炭化水素の生成量に基づいて触媒回転数を求めると、 TON = 15 (FeMo-cofactor), 13 (FeV-cofactor), 13 (L-cluster) であった。さらに、 $\mathrm{CO}_{2}$ の還元反応も辛うじて触媒的 に進行し、TON = 1.4 (FeMo-cofactor), 1.8 (FeV-cofactor), 2.3 (L-cluster) であった (Fig. 5 (4)(5)(6) 右)。なお、これ ら一連の反応で生成した炭化水素の主成分は $\mathrm{CH}_{4}$ （約 6 〜 7 割）であった。また、二番目に多い成分は、CO や $[\mathrm{CN}]^{-}$の還元では $\mathrm{C}_{2}$ 化合物（エタン、エチレン）で 2 〜 3 割、 $\mathrm{CO}_{2}$ の還元では $\mathrm{CO}(3 \sim 4$ 割) であった。こ れら以外の主要な還元生成物は、プロトンの還元により 生成する $\mathrm{H}_{2}$ であり、 $[\mathrm{CN}]^{-}$の還元反応では含炭素成分 の発生総量と同程度、 $\mathrm{CO}$ の還元反応では倍程度、 $\mathrm{CO}_{2}$ では三倍程度であった。

ここで述べた $\mathrm{C}_{1}$ 基質の還元機能が、生物学的な意味 を持つか否かは不明であるが、もし仮に進化の過程に関 連するならば、原始的なニトロゲナーゼは $\mathrm{N}_{2}, \mathrm{CO}$ 両方 の還元を担っていたものの、光合成の台頭とともに窒素 固定に特化して進化してきた、と類推することも可能で ある。

\section{文献}

1) R. R. Eady, Chem. Rev., 96, 3013 (1996).

2) J. Kim, D. C. Rees, Science, 257, 1677 (1992).

3) O. Einsle, F. A. Tezcan, S. L. A. Andrade, B. Schmid, M. Yoshida, J. B. Howard, D. C. Rees, Science, 297, 1696 (2002).

4) T. Spatzal, M. Aksoyoglu, L. Zhang, S. L. A. Andrade, E. Schleicher, S. Weber, D. C. Rees, O. Einsle, Science, 334, 940 (2011).

5) K. M. Lancaster, M. Roemelt, P. Ettenhuber, Y. Hu, M. W. Ribbe, F. Neese, U. Bergmann, S. DeBeer, Science, 334, 974 (2011).

6) J. A. Wiig, Y. Hu, C. C. Lee, M. W. Ribbe, Science, 337, 1672 (2012).

7) J. A. Wiig, C. C. Lee, Y. Hu, M. W. Ribbe, J. Am. Chem. Soc., 135, 4982 (2013).

8) J. B. Broderick, B. R. Duffus, K. S. Duschene, E. M. Shepard, Chem. Rev., 114, 4229 (2014).

9) J. T. Kaiser, Y. Hu, J. A. Wiig, D. C. Rees, M. W. Ribbe, Science,
331, 91 (2011).

10) R. Y. Igarashi, M. Laryukhin, P. C. Dos Santos, H. -I. Lee, D. R. Dean, L. C. Seefeldt, B. M. Hoffman, J. Am. Chem. Soc., 127, 6231 (2005).

11) D. Lukoyanov, Z. -Y. Yang, D. R. Dean, L. C. Seefeldt, B. M. Hoffman, J. Am. Chem. Soc., 132, 2526 (2010).

12) Z. - Y. Yang, N. Khadka, D. Lukoyanov, B. M. Hoffman, D. R. Dean, L. C. Seefeldt, Proc. Natl. Acad. Sci. U.S.A., 110, 16327 (2013).

13) D. Lukoyanov, Z. -Y. Yang, N. Khadka, D. R. Dean, L. C. Seefeldt, B. M. Hoffman, J. Am. Chem. Soc., 137, 3610 (2015).

14) T. Spatzal, K. A. Perez, O. Einsle, J. B. Howard, D. C. Rees, Science, 345, 1620 (2014).

15) For example, see: B. M. Barney, H. -I. Lee, P. C. Dos Santos, B. M. Hoffman, D. R. Dean, L. C. Seefeldt, Dalton Trans., 2277 (2006).

16) D. Smith, K. Danyal, S. Raugei, L. C. Seefeldt, Biochemistry, 53, 2278 (2014)

17) J. Vela, S. Stoian, C. J. Flaschenriem, E. Münck, P. L. Holland, $J$. Am. Chem. Soc., 126, 4522 (2004).

18) S. Ohta, Y. Ohki, T. Hashimoto, R. E. Cramer, K. Tatsumi, Inorg. Chem., 51, 11217 (2012).

19) J. S. Anderson, J. Rittle, J. C. Peters, Nature, 501, 84 (2013).

20) C. C. Lee, Y. Hu, M. W. Ribbe, Science, 329, 642 (2010).

21) C. C. Lee, Y. Hu, M. W. Ribbe, Angew. Chem. Int. Ed., 50, 5545 (2011).

22) Y. Hu, C. C. Lee, M. W. Ribbe, Science, 333, 753 (2011).

23) Z. -Y. Yang, D. R. Dean, L. C. Seefeldt, J. Biol. Chem. 286, 19417 (2011).

24) J. G. Rebelein, Y. Hu, M. W. Ribbe, Angew. Chem. Int. Ed. 53, 11543 (2014).

25) Z. -Y. Yang, V. R. Moure, D. R. Dean, L. C. Seefeldt, Proc. Natl. Acad. Sci. U.S.A. 109, 19644 (2012).

26) C. C. Lee, Y. Hu, M. W. Ribbe, Angew. Chem. Int. Ed., 51, 1947 (2012).

27) C. C. Lee, Y. Hu, M. W. Ribbe, Angew. Chem. Int. Ed., 54, 1219 (2015). 